\title{
KEMAMPUAN PEMAHAMAN MATEMATIS SISWA MELALUI PENDEKATAN SAINTIFIK DENGAN TIPE SOAL OPEN ENDED
}

\author{
Novi Fauziyah ${ }^{1}$, Runisah ${ }^{2}$, Mochammad Taufan ${ }^{3}$ \\ Universitas Wiralodra, Indramayu ${ }^{1,2,3}$ \\ Email: Novifauziyah5@gmail.com ${ }^{1}$,runisah@unwir.ac.id², \\ mochammad.taufan@unwir.ac.id ${ }^{3}$
}

\begin{abstract}
Abstrak. Tujuan penelitian ini untuk mengkaji kemampuan pemahaman matematis siswa melalui penggunaan pendekatan saintifik dengan soal open ended dan pendekatan saintifik tanpa soal open ended. Selain itu, penelitian ini bertujuan untuk mengetahuai pengaruh pemberian soal open ended pada pendekatan Saintifik terhadap kemampuan pemahaman matematis siswa. Penelitian menggunakan metode kuasi eksperimen dengan populasi terdiri dari siswa kelas VIII di salah satu sekolah di Kabupaten Indramayu, Jawa Barat. Sampel diambil dua kelas dengan menggunakan teknik simple random sampling. Satu kelas belajar melalui pendekatan saintifik dengan pemberian soal open ended, sedangkan kelas lain menggunakan pendekatan Saintifik tanpa pemberian soal open ended. Berdasarkan hasil penelitian, kemampuan pemahaman matematis siswa melalui penggunaan pendekatan saintifik dengan soal open ended dan pendekatan saintifik tanpa soal open ended masih rendah. Tidak terdapat pengaruh pemberian soal open ended pada pendekatan saintifik terhadap kemampuan pemahaman matematis siswa.
\end{abstract}

\section{Kata kunci: $\quad$ Open Ended, Pemahaman Matematis, Pendekatan Saintifik.}

\begin{abstract}
The purpose of this study is to examine students' mathematical understanding ability through the use of scientific approaches with open ended problems and scientific approaches without open ended problems. In addition, this study aims to explore the influence of open ended problems on scientific approaches to students' mathematical understanding ability The study used quasi-experimental methods with a population consisting of grade VIII students in one of the schools in Indramayu Regency, West Java. Samples were taken in two classes using simple random sampling techniques. One class learned through a scientific approach by giving open ended problems, while the other class used a Scientific approach without giving open ended problems. Based on the results of the study, students' mathematical understanding ability through the use of scientific approaches with open ended problems and scientific approaches without open ended problems are still low. There is no effect of giving open ended problems on scientific approaches to students' mathematical understanding ability
\end{abstract}

\section{Keywords: $\quad$ Open Ended, Mathematical Understanding, Scientific Approach}

\section{A. Pendahuluan}

Kemampuan pemahaman matematis sebagai salah satu kunci kesuksesan dalam proses pembelajaran. Kemampuan pemahaman matematis bagian yang sangat penting dalam pembelajaran matematika. Pemahaman konsep matematika diartikan sebagai pemahaman yang bersifat universal terhadap konsep matematika (Kilpatrick et al., 2001) sebagai dasar untuk menyelesaikan permasalahan matematika (Karim dan Nurrahmah, 2018; Lambertus, 2016) maupun permahasalahan sehari hari (Lambertus, 2016). Pemahaman merupakan inti dalam setiap aktivitas yang melibatkan matematika. (Minarni, Napitupulu dan Husein, 2016). Oleh karena itu kemampuan pemahaman matematis menjadi salah satu tujuan dalam pembelajaran matematika.

Kenyataannya, masih banyak siswa dengan kemampuan pemahaman matematis yang masih rendah. Sumarmo menemukan bahwa kemampuan siswa dalam pemahaman masih rendah dan siswa masih banyak mengalami kesukaran dalam pemahaman relasional (Purwasih, 2015). Susanti, Murni, dan Anggraini (2015) menjelaskan bahwa ketidakmampuan sebagian 
peserta didik menunjukkan bahwa kurangnya pemahaman terhadap materi yang diberikan oleh guru. Asria (2019) berdasarkan penelitiannya menemukan bahwa kemampuan pemahaman konsep siswa masih rendah.

Rendahnya kemampuan pemahaman matematis siswa salah satunya disebabkan pembelajaran yang tidak melibatkan siswa secara aktif dalam membangun pengetahuan untuk meningkatkan kemampuan pemahaman matematis (Susanti, dkk., 2015). Menurut Purwasih (2015) penyebab rendahnya kemampuan pemahaman siswa, antara lain siswa sudah terbiasa mempelajari konsep dan rumus-rumus matematika dengan cara menghafal tanpa memahami maksud, isi, dan kegunaanya. Selanjutnya menurut Nugraha (2018) faktor-faktor penyebab rendahnya kemampuan pemahaman matematis meliputi: (1) kurang baiknya kemampuan guru dalam aspek pemahaman masalah yang berdampak pada kemampuan pemahaman masalah matematis siswa, (2) strategi untuk melatih kemampuan pemahaman masalah matematis siswa belum tepat, (3) kurangnya minat siswa dalam belajar matematika. Menurut Deswita, Kusumah, dan Dahlan (2018) siswa belum mampu memahami konsep matematis dengan baik, serta siswa juga belum mampu menyatakan suatu situasi atau masalah dengan mempresentasikan simbol, diagram, atau model matematis sehingga pembelajaran masih berpusat pada guru.

Salah satu bentuk kegiatan yang berpotensi untuk dapat meningkatkan pemahaman siswa yaitu melalui pemberian soal open ended. Menurut Takahashi (Cahyani dan Manoy, 2017) soal open-ended adalah soal dengan banyak solusi atuapun strategi dalam menyelesaikannya. Menurut Ruslan dan Santoso (2013) tujuan dari pemberian soal open ended untuk meningkatkan kegiatan kreatif siswa dan berpikir matematika agar berkembang secara maksimal, memberikan kebebasan siswa untuk berpikir dalam membuat progress pemecahan sesuai dengan kemampuan, sikap dan minatnya melalui berbagai strategi dan cara yang diyakininya dalam menyelesaikan masalah sehingga membentuk intelegensi matematika siswa. Selanjutnya Badger dan Thomas (Nurlita, 2015) menjelaskan bahwa fokus dari soal-soal open ended yaitu pemahaman siswa, kemampuan mereka untuk berpikir, dan menerapkan untuk menyelesaikan masalah non rutin. Demikian, dengan adanya pemberian tipe soal open ended pada siswa untuk mencapai tujuan dalam meningkatkan kemampuan pemahaman matematis siswa dalam proses pembelajaran.

Pembelajaran yang bertujuan untuk meningkatkan kemampuan siswa secara optimal termasuk kemampuan pemahaman matematis siswa harus dilakukan melalui langkah terstruktur dan terukur. Salah satu cara untuk menyusun pembelajaran yang sesuai dengan prinsip tersebut ialah menggunakan pendekatan saintifik. Menurut Widiani, Rif'at, dan Ijuddin (2016) penerapan pendekatan saintifik dalam pembelajaran melibatkan keterampilan proses seperti mengamati, mengklasifikasi, mengukur, meramalkan, dan menyimpulkan. Selanjutnya, Nurrohmah (2015) menemukan bahwa pendekatan saintifik mempunyai efektivitas tinggi dalam meningkatkan hasil belajar tiap aspek kognitif siswa pada jenjang pengetahuan, pemahaman, dan penerapan..

Tujuan penelitian ini adalah untuk mengetahui kemampuan pemahaman matematis siswa dengan menggunakan pendekatan saintifik dalam pembelajaran yang diberikan tipe soal open ended dan yang tidak diberikan soal open ended. Selain itu penelitian ini bertujuan untuk melihat pengaruh pemberian tipe soal open ended dalam pembelajaran terhadap kemampuan pemahaman matematis siswa dengan menggunakan pendekatan saintifik. 


\section{B. Metode Penelitian}

Penelitian ini merupakan penelitian kuasi eksperimen dengan Control Group post-test only design. (Senjaya, 2017). Populasi yang ditetapkan dalam penelitian ini adalah siswa kelas VIII di salah satu sekolah di Indramayu. Teknik pengambilan sampel menggunakan teknik simple random sampling.

Baik kelas kontrol maupun kelas eksperimen digunakan pendekatan saintifik. Aktivitas pembelajaran melibatkan kegitan mengamati (observasi), menanya, mengumpulkan informasi, mengasosiasikan/ mengolah informasi/ menalar, menarik kesimpulan, dan mengkomunikasikan. Pada kelas eksperimen diberikan soal soal open ended sebagai latihan sedangkan pada kelas kontrol diberikan soal rutin.

Instrumen untuk mengukur kemampuan pemahaman matematis siswa berupa 5 soal yang berbentuk uraian. Indikator kemampuan pemahaman matematis terdiri dari (a) kemampuan mengklasifikasi objek-objek berdasarkan persyaratan yang membentuk konsep tersebut. (b) kemampuan memberikan contoh dan non contoh dari konsep yang telah dipelajari. (c) kemampuan menerapkan konsep secara algoritma.

\section{Hasil Penelitian dan Pembahasan}

Berdasarkan hasil penelitian, dari skor maksimum ideal 20, pada kelas eksperimen diperoleh skor rata-rata sebesar 5,50 dan varian sebesar 11,20, sedangkan kelas kontrol diperoleh skor rata-rata sebesar 5,20 dan varian sebesar 13,46. Hasil tersebut dilihat pada Gambar 1

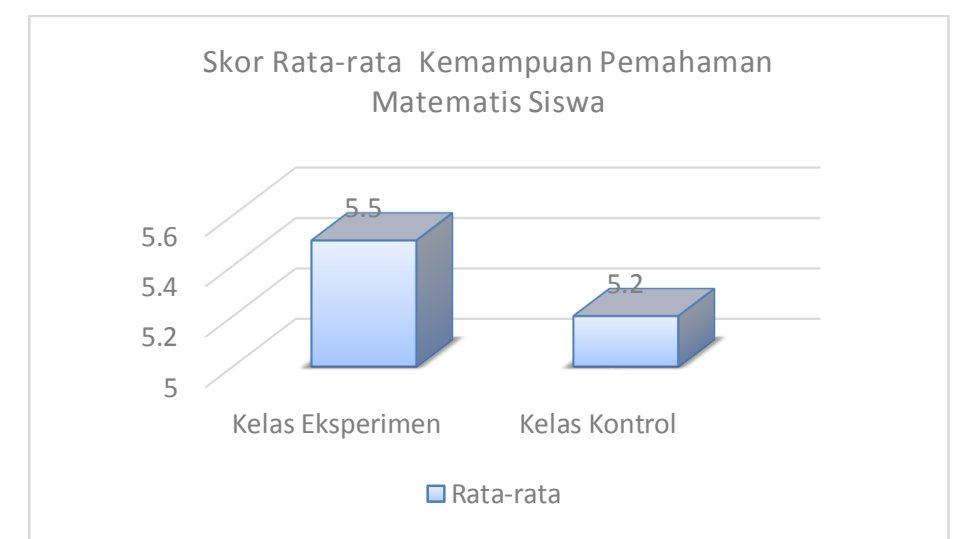

Gambar 1 Skor Rata-Rata Kemampuan Pemahaman Matematis Siswa

Berdasarkan Gambar 1, skor rata-rata kemampuan pemahaman matematis siswa kelas eksperimen dan kelas kontrol tidak memiliki perbedaan yang jauh. Selain itu, nampak bahwa rata rata skor tersebut masih jauh dari skor maksimum ideal. Dengan demikian baik kelas eksperimen maupun kelas kontrol masih memiliki kemampuan pemahaman yang rendah.

Selanjutnya dilakukan uji normalitas dengan menggunakan Uji Lillifors. Hasil uji normalitas dinyatakan pada Tablel 1:

Tabel 1 Hasil Uji Normalitas

\begin{tabular}{ccc}
\hline Kelas & $\mathbf{L}_{\mathbf{0}}$ & $\mathbf{L}_{\mathbf{k}}$ \\
\hline Eksperimen & 0,189 & 0,221 \\
Kontrol & 0,202 & 0,229 \\
\hline
\end{tabular}

Berdasarkan Tabel 1, pada kelas eksperimen diperoleh Lo $=0,189$, untuk $\alpha=0,05$ didapat $\mathrm{Lk}=0,221$. Karena $\mathrm{Lo}<\mathrm{Lk}$ maka disimpulkan bahwa sampel berasal dari populasi 
berdistribusi normal. Pada kelas kontrol di peroleh $\mathrm{Lo}=0,202$ dan $\mathrm{Lk}=0,229$, artinya sampel berasal dari populasi berdistribusi normal.

Selanjutnya dilanjutkan dengan uji homogenitas varians dengan uji Fisher, yang disajikan pada Tabel 2.

\section{Tabel 2 Hasil Uji Homogenitas Dua Varians}

\begin{tabular}{cccc}
\hline Kelas & varians & $\mathbf{F}_{\text {obs }}$ & $\mathbf{F}_{\text {kritis }}$ \\
\hline Eksperimen & 11,20 & 1,2 & 3,56 \\
Kontrol & 13,46 & & \\
\hline
\end{tabular}

Berdasarkan uji homogenitas varians dengan taraf signifikan $(\alpha)=0,05$, diperoleh $\mathrm{F}_{o}=$ 1,2 dan $\mathrm{F}_{k}=3,56$. Berdasarkan kriteria uji homogenitas dapat disimpulkan bahwa $\mathrm{F}_{o}<\mathrm{F}_{k}$, dengan demikian kedua varians homogen.

Perhitungan selanjutnya dilakukan dengan menggunakan uji $t$, hasil perhitungan ditunjukkan pada Tabel 3.

Tabel 3 Uji Kesamaan Dua Rata-Rata (Uji t)

\begin{tabular}{cccccc}
\hline Kelas & Rata-rata & $\mathbf{S}$ & $\mathbf{S}_{\mathbf{g a b}}$ & $\mathbf{t}_{\mathbf{o b s}}$ & $\mathbf{t}_{\mathbf{k}}$ \\
\hline Eksperimen & 5,50 & 3,35 & \multirow{2}{*}{12,29} & 0,24 & 2,05 \\
Kontrol & 5,20 & 3,67 & & & \\
\hline
\end{tabular}

Dari Tabel 3 dengan taraf signifikan $(\alpha)=0,05$ tobs $=0,24$ dan tk $=2,05$. Dengan demikian tobs $<$ tk artinya tidak ada perbedaan kemampuan pemahaman matematis antara kelas yang diberikan tipe soal open ended dengan yang tidak diberikan tipe soal open ended. Hal ini berarti tidak terdapat pengaruh pemberian tipe soal open ended dalam pembelajaran matematika terhadap kemampuan pemahaman matematis siswa dengan menggunakan pendekatan saintifik.

\section{Pembahasan}

Berdasarkan hasil penelitian, dari skor maksimum ideal 20 pada kelas eksperimen diperoleh skor rata-rata sebesar 5,50 dan kelas kontrol sebesar 5,20. Hal tersebut menunjukan rendahnya kemampuan pemahaman siswa. Salah satu faktor yang menyebabkan rendahnya pemahaman siswa tersebut yaitu penguasaan materi prasyarat. Hal ini dapat dilihat dari jawaban hasil tes kemampuan pemahaman yang menunjukkan masih banyak siswa menjawab soal dengan salah karena kurangnya penguasaan materi prasyarat. Sebagai contoh dapat dilihat pada jawaban soal nomor 1 .

Soal 1

Tentukan rumus jumlah $\mathrm{n}$ suku pertama dari deret aritmatika $2+4+6+8+\ldots$

Sebagai contoh jawaban siswa terhadap soal tes berikut disajikan pada Gambar 2

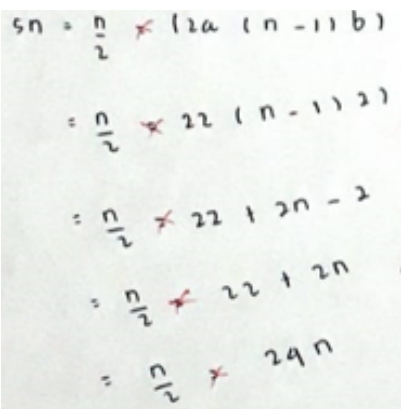

Gambar 2. Contoh jawaban siswa yang salah

Dari Gambar 2 terlihat bahwa siswa melakukan kesalahan dalam melakukan operasi bentuk aljabar. Pada langkah pertama siswa menuliskan rumus dengan benar. Siswa sudah bisa 
menentukan suku pertama $a=2$ dan $b=2$. Namun pada saat menggantikan nilai a pada $2 a$, siswa menjawab bahwa $2 \mathrm{a}=22$. Seharusnya $2 \mathrm{a}=2.2=4$. Selanjutnya siswapun menjawab bahwa $22+2 n=24 n$ yang merupakan jawaban yang salah. Berdasarkan jawaban tersebut siswa salah dalam menjawab soal karena belum memahami materi sebelumnya yaitu operasi penjumlahan dan perkalian bentuk aljabar. Hal ini sejalan dengan pendapat Aminah, ,Kusumah, Suryadi dan Sumarmo bahwa untuk menguasai konten matematika dan proses matematika yang kompleks dibutuhkan pemahaman materi sebelumnya dengan baik (Runisah, 2019).

Selanjutnya hasil penelitian menunjukkan bahwa kemampuan pemahaman matematis siswa tidak dipengaruhi oleh pembelajaran dengan soal open ended yang menggunakan pendekatan saintifik. Hasil penelitian ini tidak sejalan dengan beberapa hasil penelitian terdahulu. Suastika dan Safrina (2016) menunjukkan bahwa pembelajaran yang dilaksanakan menggunakan soal terbuka dengan Scaffolding dapat meningkatkan pemahaman materi bilangan bulat bagi mahasiswa PGSD Universitas Kanjuruhan Malang. Ruslan dan Santoso (2013) menyimpulkan bahwa terdapat perbedaan peningkatan kemampuan penalaran matematis siswa antara siswa yang diberi soal open-ended dengan pemberian soal rutin. Nissa, Lestari, dan Kumala (2019) yang mengungkapkan bahwa diberikannya soal matematika dalam bentuk open-ended problems kepada siswa dalam pembelajaran materi program linier dapat memberikan pengaruh terhadap kemampuan pemecahan masalah.

Faktor yang mungkin dapat menyebabkan tidak berpengaruhnya pemberian tipe soal open ended dalam pembelajaran matematika terhadap kemampuan pemahaman matematis siswa pada penelitian ini diantaranya yaitu jam belajar yang sangat terbatas. Penelitian ini dilakukan di pesantren sehingga banyak mata pelajaran khusus keagamaan yang memerlukan hapalan dibandingkan di sekolah umum. Hal inilah diantaranya yang berdampak lebih terbatasnya waktu untuk belajar mata pelajaran umum.

Selain terbatasnya waktu belajar, siswa tidak terbiasa untuk mengerjakan soal soal tipe open ended. Hal ini terlihat pada saat mengerjakan latihan soal open ended, para siswa masih belum mampu memahami soal yang diberikan dan siswa masih merasa kesulitan dalam menentukan strategi berbeda ataupun penyelesaian yang berbeda Hal itu dikarenakan untuk mengerjakan soal open ended dibutuhkan kefleksibelan dalam berpikir. Hal ini sejalan dengan pendapat Emilya bahwa kreativitas siswa dituntut untuk menyelesaikan soal openended.(Cahyani dan Manoy, 2017). Selain itu menurut Suherman, dkk (2001) kelemahan soal open ended yaitu sangat sulitnya mngemukakan masalah yang langsung dapat dipahami siswa sehingga banyak siswa yang mengalami kesulitan dalam merespon permasalahan yang diberikan, Sementara itu untuk siswa berkemampuan tinggi bisa merasa ragu atas jawaban mereka,

Namun demikian sebenarnya jika dilihat dari proses pembelajaran siswa pada kelas eksperimen lebih aktif dalam belajar jika dibandingkan dengan siswa kelas kontrol. Aktivitas belajar pada kelas eksperimen dan kelas kontrol disajikan pada Gambar 2.

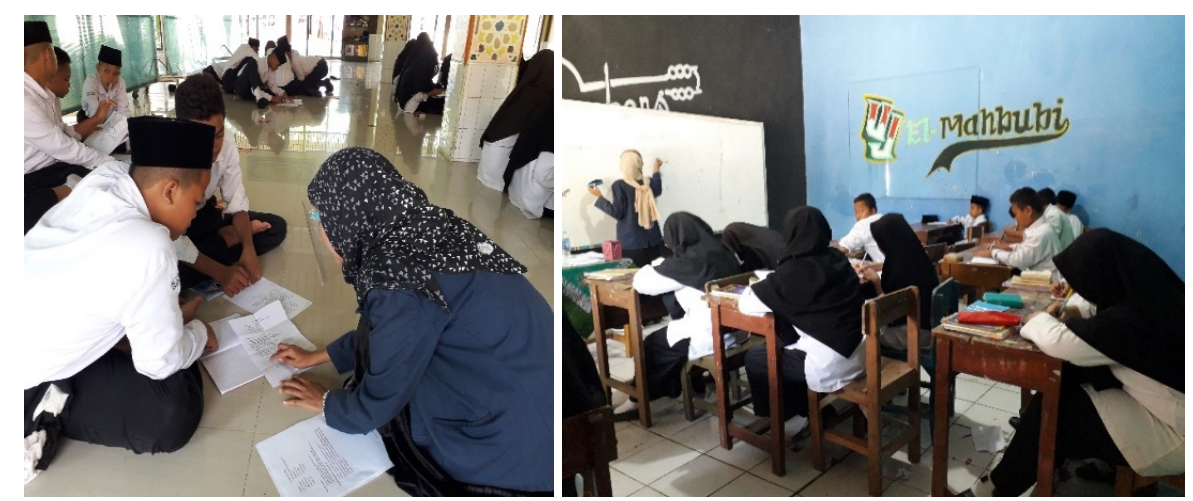


Gambar 3. Siswa Kelas eksperimen (kiri) dan siswa kelas Kontrol (kanan)

Pada Gambar 2 terlihat bahwa siswa kelas eksperimen lebih aktif dalam belajar. Hal ini sejalan dengan Suherman, dkk (2001) bahwa soal open ended dapat menjadikan siswa berpartisipasi lebih aktif dalam pembelajaran dan sering mengekspresikan ide-ide. Dari hasil penelitian ini pemberian soal open ended dapat lebih mengaktifkan siswa dalam belajar.

\section{E. Kesimpulan}

Kemampuan pemahaman matematis masih rendah, baik pada siswa yang menerima pendekatan saintifik dengan soal open ended, maupun siswa yang tidak diberi soal open ended. Hasil penelitian lain menunjukan tidak terdapat pengaruh pemberian tipe soal open ended dalam pembelajaran matematika terhadap kemampuan pemahaman matematis siswa dengan menggunakan pendekatan saintifik.

\section{F. Ucapan Terimakasih}

Penulis menyampaikan banyak ucapan terimakasih kepada Bapak. Farid Gunadi, M.Pd., selaku ketua Program Studi Pendidikan Matematika dan staf pengajar di SMP Islam Al-Ishlah Boarding School yang telah memfasilitasi peneliti selama penelitian ini berlangsung.

\section{DAFTAR PUSTAKA}

Asria, V. Z. 2019. Improving concept comprehension ability in mathematics by using mathematical model: Think-pair-share approach. Journal of Physics: Conference Series 1402(7): 1-7.

Cahyani, F. D., dan Manoy, J. T. 2017. Pengembangan Soal Matematika Open-Ended untuk Materi Segiempat dan Segitiga. Mathedunesa 1(10): 1-9

Karim, A., dan Nurrahmah, A. 2018. Mahasiswa Pada Mata Kuliah Teori Bilangan. Jurnal Analisa 4(1): 24-32.

Kilpatrick, J., Swafford, J., \& Findel, B. 2001. Adding + it UP: Helping Children Learn Mathematics. In National Academy Press. Washington, DC.

Lambertus. 2016. Developing skills understanding of mathematical. International Journal of Education and Research, 4(7), 315-326. Retrieved from https://www.ijern.com/journal/2016/July-2016/25.pdf

Minarni, A., Napitupulu, E. E., \& Husein, R. 2016. Mathematical understanding and representation ability of public junior high school in North Sumatra. Journal on Mathematics Education, 7(1), 43-56. https://doi.org/10.22342/jme.7.1.2816.43-56

Deswita, R., Kusumah, Y, S., dan Dahlan J, A. 2018. Peningkatan Kemampuan Komunikasi Matematis Siswa Melalui Model Pembelajaran CORE dengan Pendekatan Scientific. Edumatika Jurnal Riset Pendidikan Matematika 1(1): 35-43. 
Nissa, I. C., Lestari, P., dan Kumala, D. 2019. Pengaruh Pemberian Soal Matematika Jenis Open-Ended Problems Terhadap Kemampuan Siswa Memecahkan Masalah Program Linier. Prisma Sains: Jurnal Pengkajian Ilmu dan Pembelajaran Matematika dan IPA IKIP Mataram 7(2): 126-137.

Nugraha, H. 2018. Meningkatkan Pemahaman Matematika Siswa SMP Negeri 1 Pagaden Kelas VIII dengan Gamification Kahoot. UJMES (Uninus Journal of Mathematics Education and Science) 3(1): 148-154.

Nurlita, M. 2015. Pengembangan Soal Terbuka (Open-Ended Problem) pada Mata Pelajaran Matematika SMP Kelas VIII. Pythagoras: Jurnal Pendidikan Matematika 10(1): 38-49.

Suherman, E dkk. 2001.Common Text Book; Strategi Pembelajaran MatematikaKontemporer. Bandung : JICA-UPI

Nurrohmah, E. F. 2015. Efektivitas Pendekatan Saintifik dalam Meningkatkan Hasil dan Motivasi Belajar Siswa SMP. Universitas Pendidikan Indonesia. Repsitory auniversity Indonesia of Education. Bandung.

Purwasih, R. 2015. Peningkatan Kemampuan Pemahaman Matematis dan Self Confidence Siswa MTs di Kota Cimahi Melalui Model Pembelajaran Inkuiri Terbimbing. Jurnal Ilmiah STKIP Siliwangi Bandung 9(1): 16-25.

Runisah 2019 The effect of 5E learning cycle with metacognitive techniques and mathematical prior ability on mathematical creative thinking skills J. Phys.: Conf. Ser. 1315012082

Ruslan, A. S., dan Santoso, B. 2013. Pengaruh Pemberian Soal Open-Ended Terhadap Kemampuan Penalaran Matematis Siswa. Kreano, Jurnal Matematika Kreatif-Inovatif 4(2): $138-150$.

Senjaya, A. J. 2017. Statistika Terapan untuk Penelitian Bidang Pendidikan dan Pengajaran. Edisi Pertama. Cetakan Pertama. Fkipunwir Press. Indramayu.

Suastika, I. K., dan Safrina, M. (2016). Penggunaan Soal Terbuka dengan Scaffolding untuk Meningkatkan Pemahaman Materi Bilangan Bulat Bagi Mahasiswa PGSD Universitas Kanjuruhan Malang. Jurnal Inspirasi Pendidikan 6(2): 857-865.

Susanti, E., Murni, A., dan Anggraini, R. D. 2015. Upaya Meningkatkan Kemampuan Pemahaman Matematis Peserta Didik Kelas X Mia 2 Man 2 Model Pekanbaru Melalui Penerapan Discovery Learning. Jurnal Online Mahasiswa Fakultas Keguruan dan Ilmu Pendidikan Universitas Riau 2(2): 1-11.

Widiani, T., Rif'at, M., dan Ijuddin, R. 2016. Penerapan Pendekatan Saintifik dan Pengaruhnya Terhadap Kemampuan Komunikasi Matematis dan Berpikir Kreatif Siswa. jurnal pendidikan dan pembelajaran khatulistiwa 5(1), 1-14. 